open $\bigcirc$ ACcess

Authors' contribution:

A) conception and design of the study

B) acquisition of data

C) analysis and interpretation of data

D) manuscript preparation

E) obtaining funding

Received: 15.06.2021

Accepted: 15.10 .2021

\title{
The Corruption Formation Process in Iranian Football
}

\author{
Hossein Mansouri ${ }^{1 A-D}$ (D), Saeed Sadaghi Boroujerdi ${ }^{1 A-C}$ (D), \\ Geoff Dickson ${ }^{2}$ C-D ID, Rasool Norouzi Seyed Hossini ${ }^{3}$ A-C (D) \\ ${ }^{1}$ University of Kurdistan, Sanandaj, Iran \\ ${ }^{2}$ La Trobe Business School, La Trobe University, Melbourne, Australia \\ ${ }^{3}$ Tarbiat Modares University, Tehran, Iran
}

*Correspondence: Hossein Mansouri, University of Kurdistan, Pasdaran Sreet, Sanandaj, Kurdistan Province, email: hoseinmansouri66@gmail.com

\begin{abstract}
This study investigates the corruption formation process in Iranian football. Data was collected using library studies as well as 18 in-depth and semi-structured interviews with football industry stakeholders. The research data were analyzed through the coding process in three stages: open, pivotal and selective. Grounded Theory was used to determine the initial list of corruption causes. Then, interpretive structural modeling and MICMAC analysis were utilized. Having analyzed the data, the researchers classified the variables into four different levels, and after MICMAC analysis, we divided the variables into two groups of independent and dependent variables. None of the variables were included in the group of autonomous and linkage variables. The results showed that at the highest level, corrupt governance of football (including weak football federation statutes, government control of football, and weak governance in football) was the most influential factor. At the third level, the key factor was structural dysfunction which was underpinned by both weak management and supervision in football. At the second level, defective agreements and monitoring (consisting of weak rules and regulations and inefficient national and club contracts) was significant. At the first level, financial dysfunction (including money laundering and economic and financial factors), bias and opportunism (by journalists and agents), and corruption of human resources (comprising coercion and nurturing corrupt forces) were influential. The findings showed that the managerial level has a major role in preventing corruption.
\end{abstract}

Keywords: Corruption, transparency, accountability, structural-interpretive modeling, governance, sport

\section{Introduction}

Corruption is calculated crime, normally perpetrated for economic gain (Agatiello, 2010). Corruption occurs when "an agent deviates from moral rules considered relevant and consolidated in a particular social context, while the integrity involves acting according to basic moral values and rules" (Monteduro, Hinna \& Moi, 2016, p. 36). Elsewhere, corruption refers to the abuse of entrusted power for undue and private gain (Hauser \& Hogenacker, 2014). Corruption incorporates many types of behaviours and activities (Graycar 2017). Corrupt behaviours include bribery, extortion, misappropriation, self-dealing, patronage, abuse of discretion, misuse of information, creating or exploiting a conflict of interest, as well as nepotism, clientelism, and favouritism. 
Corrupt activities include appointing personnel, procuring services, making things (construction and manufacturing), rebuilding things (after a disaster), controlling activities (i.e., licensing, regulating, issuing of permits) and administering justice.

There is a consensus that corruption has multidimensional and detrimental impacts including economic instability, social inequality, inefficiency and resource waste (Monteduro, Cecchetti, Ylenia, \& Allegrini, 2021). Corruption can destroy a firm's reputation, and subsequently degrade social capital, compromise its market position, or devalue the firm (Kim \& Wagner, 2020). Widespread corruption is considered a sign of weak governance, and poor anticorruption processes can undermine the process of economic growth and development (Nunkoo et al., 2018).

Sport is no stranger to corruption. The evolution of sport into a complex industry encourages opportunism and corrupt behaviours (Buraimo et al., 2012). Corruption threatens the integrity of sports (Moriconi, 2020). Consequently, corruption is a major challenge for sports managers (Kihl et al., 2017) and sport managers must be prepared to deal with all kinds of corruption (Gorse \& Chadwick, 2011). The influx of money into a globalized sport industry has led to some corrupt practices, and a so-called dark side of sport. Common examples of corruption in sport include manipulating the results, selling votes, conflicts of interest, bribery, collusion, extortion, and betting (Philippou, 2019; Mansouri et al., 2019; Andreff, 2018; Kihl et al., 2017; Brooks et al., 2013; Gorse \& Chadwick, 2011). Within in international football, Pielke (2013) points out that bribery and vote-buying are part of FIFA's structure. In addition, the concentration of power in the hands of very few people, lack of supervision and accountability, and extraordinary profitability of football all contribute to FIFA's integrity issues. Even the Olympic Games has been linked to such practices (Matheson et al., 2018).

Corruption is problematic for sport for at least four reasons. First, corruption violates sport and its fair play ethos (Andreff, 2018). Second and third, corruption undermines the rule of law and those who engage in corruption engage in deviant behavior (Weitz-Shapiro, \& Winters, 2017). Corruption is powerful enough to destroy not only institutions or a system but also the entire legal and social structure of a country (Olmos, Bellido \& Román-Aso, 2020). The public, the media, and politicians are all aware of the long-term and harmful effects of corruption on the economy and society (Dimant, 2014). The mass media's interest in corruption and the emergence of anti-corruption movements have highlighted public and academic discourses on corruption in sports and major events (Müller, 2015). Finally, all of these have the potential to impact negatively the image of the sport and the sport's governing organizations (Hallmann, Dickson, \& Giese, 2020),

Corruption in sport exists at two levels: competitive and organizational. Competitive corruption tries to affect the results of the competitions, and organizational corruption attempts to negatively affect the organizational structure and planning of major sporting events (Nunkoo et al., 2018). In Iran, both competitive and organizational corruption is observed (Mansouri et al., 2019; Ghorbani et al., 2019).

Corruption in sports (in all its forms and levels) is a global phenomenon, Corruption in sport has been studied in a variety of countries. These include Romania (Constantin, \& Stănescu, 2021), Zimbabwe (Dandah \& Chiweshe, 2021), USA (Kihl, Ndiaye, \& Fink,, 2018), Sri Lanka (Madhushani, 2019), the Balkan countries (Manoli, \& Janečić, 2020), Greece and Turkey (Manoli, Yilmaz, \& Antonopoulos, 2021), Brazil (Marchetti, Reppold Filho, \& Constandt, 2021), India (Ghai \& Zipp, 2020), Taiwan (Tzeng \& Lee, 2021) and sub-Saharan African nations (Stathopoulou, Quansah, \& Balabanis, 2021). Studies by Najafi et al. (2020), Mansouri et al. (2019), Ghorbani et al. (2019), Mahmoudi et al. (2019), and Goodarzi et al. (2010) explore sport-related corruption in Iran. These studies highlight the government control of Iranian sports, opportunism, cultural factors, weak rules and regulations, lack of proper monitoring, lack of competence among sports managers, betting, collusion, and lack of transparency as the influential factors underpinning of corruption in Iranian sport.

This study is guided by two related research questions. First, we ask, what is the appropriate categorization of corruption formation in Iranian football? Separation of the system into different levels helps clarify the role of each variable and the interaction between and amongst variables. This question is addressed using Interpretive Structural Modeling (ISM). Second, we ask, what are the effective independent and linkage variables and influential dependent and autonomous variables in the formation of corruption in the Iranian football industry? This question is answered on the basis of a MICMAC analysis.

The results of this study have both theoretical and practical implications. Theoretically, this study identifies the influential dependent variables in the corruption equation. In the practical part, having identified these variables, policy makers can better implement anti-corruption policies. This study can also be used by organizations and regulatory authorities to benchmark appropriate behaviours, practices, and policies. In turn, this will promote stakeholder confidence in the Iranian football industry. 


\section{Methods}

This study provides a model explaining the formation of corruption in the Iranian football industry. Using grounded theory elements, the study first identified the causes of corruption in football. Then, the data were analyzed through Interpretive Structural Modeling (ISM) and the Cross-Impact Matrix Multiplication Applied to Classification (MICMAC) methodologies.

\section{Data Collection}

We deployed a purposive/judgmental approach to sampling. Participants were selected on the basis of their expertise within the sport football industry. Semi-structured interviews were conducted with 18 experts. The experts were selected based on purposive sampling. In terms of the level of education, seven individuals had professional doctoral degrees, three were Ph.D. students, two had master's degrees, and two had bachelor's degrees. Their age range was between 31 and 68 years. According to studies by Ramesh, Banwet and Shankar (2010) and Leby \& Hashim (2010), the number of participants in ISM studies is usually between 14 and 20.

\section{Interpretive Structural Modeling}

With ISM, the relations among the components and the leveling among them are presented (Warfield, 1974). ISM helps researchers to better understand what is both known and not known (Farris \& Sage, 1975). ISM uses a complex system to analyze and solve problems in decision-making to visualize, create, and understand a hierarchical structure. It is a structural approach, so the overall structure derived from the complex set of relationships (Azar et al., 2020). ISM identifies and regulates the complexity of the relationships among the various factors, providing a blueprint for the relationships between and amongst the factors.

We followed well-established guidelines for conducting ISM (Poduval et al., 2015; Pramod \& Banwet, 2013; Attri et al., 2012; Sushil, 2012). In ISM, each stage is related to the previous stage and cannot be omitted. The ISM technique consists of six well-defined steps.

Step 1: Identifying the Factors. In the first step, the research components were identified. In this study, the components were identified using the Grounded Theory analysis.

Step 2: Structural Matrix of the Variables' Internal Relations. In this step, using the components obtained in Step 1, the respondent was asked to specify the type of relationship between the two variables. The states and signs used in designing the matrix are as follows:

$V$ : Element $i$ leads to element $\mathrm{j}$ (variable $\mathrm{i}$ affects $\mathrm{j}$ )

A: Element $\mathrm{j}$ leads to element $\mathrm{i}$ (variable $\mathrm{j}$ affects $\mathrm{i}$ )

$\mathrm{X}$ : The relationship between $\mathrm{i}$ and $\mathrm{j}$ is mutual (the relationship is mutual)

$\mathrm{O}$ : There is no relationship between $\mathrm{i}$ and $\mathrm{j}$ (no relationship)

Step 3: Initial Reachability Matrix. The Structural Self-Interaction Matrix (SSIM) relationship symbols are converted to zero and one according to the following rules:

(1) If the (i, j) input in the SSIM matrix is equal to $V$, the $(i, j)$ input in the reachability matrix becomes 1 , and the $(j, i)$ input becomes 0 .

(2) If the (i,j) input in the SSIM matrix is equal to A, the (i,j) input in the matrix is 0 , and the $(j, i)$ input is 1 .

(3) If the $(i, j)$ input in the SSIM matrix is equal to $X$, the $(i, j)$ input in the matrix becomes 1 , and the $(j, i)$ input becomes 1 .

(4) If the (i,j) input in the SSIM matrix is $O$, the $(i, j)$ input in the matrix is 0 , and the $(j, i)$ input is 0.

Step 4: Structural Self-Interaction Matrix. This matrix was completed with the help of experts and specialists in the core process. In this matrix, the secondary relations must be controlled for further assurance. For example, if A leads to B and B leads to C, then A must lead up to C. In other words, the matrix must reflect the totality of relationships.

Step 5: Level partitioning. In this step, reachability, antecedent, and intersection sets are derived for all the variables. Here, two accessible sets and a set of prerequisites are defined to determine the level of criteria. The first line, where the intersection of the two sets is equal to the accessible set, takes precedence over the first level. After determining the level, the criterion or criteria whose level is specified from the table is removed and the process repeated until all the remaining variables' levels are determined.

Step 6: Plotting the model. The ISM network structure is then plotted based on the specified levels and the final matrix. Therefore, all criteria are placed in a hierarchy based on their influence and degree of dependence. 


\section{Findings}

Determinants of Corruption

The main determinants of corruption in Iranian football are summarized in Table 1 below.

Table 1. Main determinants of corruption in Iranian football

\begin{tabular}{ll}
\hline Category & Subcategory \\
\hline (A) Corrupt governance of football & Weak football federation statutes; Government control of football; \\
& Weak governance \\
(B) Defective agreements and supervision & Weak rules and regulations; Inefficient national and club contracts \\
(C) Corruption of human resources & Coercion; Nurturing corrupt forces \\
(D) Bias and opportunism & Biased journalism; Opportunistic agents \\
(E) Structural dysfunction & Managerial weakness in football; Weak supervision in football \\
(F) Financial dysfunction & Money laundering; Economic and financial factors \\
\hline
\end{tabular}

Structural self-interaction matrix

The Structural Self Interaction Matrix is displayed in Table 2 below.

Table 2. Structural self-interaction matrix

\begin{tabular}{|c|c|c|c|c|c|c|}
\hline Index & $\mathrm{A}$ & $\mathrm{B}$ & $\mathrm{C}$ & $\mathrm{D}$ & $\mathrm{E}$ & $\mathrm{F}$ \\
\hline Corrupt governance of football & & $\mathrm{V}$ & $\mathrm{V}$ & $\mathrm{V}$ & $\mathrm{V}$ & $\mathrm{V}$ \\
\hline Defective agreements and supervision & & & $\mathrm{V}$ & $\mathrm{V}$ & A & $\mathrm{V}$ \\
\hline Corruption of human resources & & & & A & A & $\mathrm{X}$ \\
\hline Bias and opportunism & & & & & A & $\mathrm{X}$ \\
\hline Structural dysfunction & & & & & & $\mathrm{V}$ \\
\hline Financial dysfunction & & & & & & \\
\hline
\end{tabular}

\section{Initial Reachability Matrix (RM)}

The reachability matrix is prepared using the self - interactive structural matrix; that is, using the zero-andone placement rule, the SSIM matrix is converted to a zero-and-one matrix in the form of Table 3.

Table 3. Initial reachability matrix

\begin{tabular}{|c|c|c|c|c|c|c|}
\hline Index & $\mathrm{A}$ & $\mathrm{B}$ & $\mathrm{C}$ & $\mathrm{D}$ & $\mathrm{E}$ & $\mathrm{F}$ \\
\hline Dominance of corruption & 1 & 1 & 1 & 1 & 1 & 1 \\
\hline Defective agreements and supervision & 0 & 1 & 1 & 1 & 0 & 1 \\
\hline Corruption of human resources & 0 & 0 & 1 & 0 & 0 & 1 \\
\hline Bias and opportunism & 0 & 0 & 1 & 1 & 0 & 1 \\
\hline Structural dysfunction & 0 & 1 & 1 & 1 & 1 & 1 \\
\hline Financial dysfunction & 0 & 0 & 1 & 1 & 0 & 1 \\
\hline
\end{tabular}

\section{Final reachability matrix}

The final reachability matrix was obtained by considering the transferability relationship. Thus, to obtain the final reachability matrix, we added the initial matrix to the unit matrix and then bring the resulting matrix to the power of $n$. The results are presented in Table 4. 
Table 4. Final reachability matrix

\begin{tabular}{lllllllc}
\hline Index & A & B & C & D & E & F & Influence \\
\hline Corrupt governance of football & 1 & 1 & 1 & 1 & 1 & 1 & 6 \\
Defective agreements and supervision & 0 & 1 & 1 & 1 & 0 & 1 & 4 \\
Corruption of human resources & 0 & 0 & 1 & $1 ”$ & 0 & 1 & 3 \\
Bias and opportunism & 0 & 0 & 1 & 1 & 0 & 1 & 3 \\
Structural dysfunction & 0 & 1 & 1 & 1 & 1 & 1 & 5 \\
Financial dysfunction & 0 & 0 & 1 & 1 & 0 & 1 & 3 \\
Dependence & 1 & 3 & 6 & 6 & 2 & 6 & \\
\hline
\end{tabular}

\section{Level Partitioning}

The structure of the ISM network was then plotted using the specified levels and the final matrix. Therefore, all criteria are placed in a hierarchy according to their influence and degree of dependence, which are presented in Tables 5 and 6.

Table 5. The first repetition of the reachability matrix's level segmentation

\begin{tabular}{ccccc}
\hline Level & Intersection set & Antecedent set & Reachability set & Variable \\
\hline & 1 & 1 & $1-2-3-4-5-6$ & Corrupt governance of football \\
& 2 & $1-2-5$ & $2-3-4-6$ & Defective agreements and supervision \\
1 & $3-4-6$ & $1-2-3-4-5-6$ & $3-4-6$ & Corruption of human resources \\
1 & $3-4-6$ & $1-2-3-4-5-6$ & $3-4-6$ & Bias and opportunism \\
& 5 & $1-5$ & $2-3-4-5-6$ & Structural dysfunction \\
1 & $3-4-6$ & $1-2-3-4-5-6$ & $3-4-6$ & Financial dysfunction \\
\hline
\end{tabular}

Table 6. The second to the fourth repetition of the reachability matrix's level segmentation

\begin{tabular}{lcccc}
\hline Level & Intersection set & Antecedent set & Reachability set & Variable \\
\hline 4 & 1 & 1 & $1-2-5$ & Corrupt governance of football \\
2 & 2 & $1-2-5$ & 2 & Defective agreements and supervision \\
3 & 5 & $1-5$ & $2-5$ & Structural dysfunction \\
\hline
\end{tabular}

\section{Interpretive structural model}

At this stage, an initial model is plotted using the levels of the variables and the final reachability matrix. A final model is then obtained by removing the transferability in the initial model.

\section{Influence and Dependence Degree of "MICMAC Graph Plotting"}

At this stage, the variables are classified into four groups. The first group consists of autonomous variables which have low influence and low dependence (Quadrant 1). The second group comprises dependent variables which have low influence and high dependence (Quadrant 2). The third group - linkage variables - have both high leverage and high dependence (Quadrant 3). In Quadrant 4, the independent variables have strong influence and low dependence. According to Figure 1, the corrupt governance of football, defective agreements and supervision, and structural dysfunction were placed in the independent cluster (Quadrant 4), and the variables of corruption of human resources, bias and opportunism, and financial dysfunction were situated in the dependent cluster (Quadrant 2). 


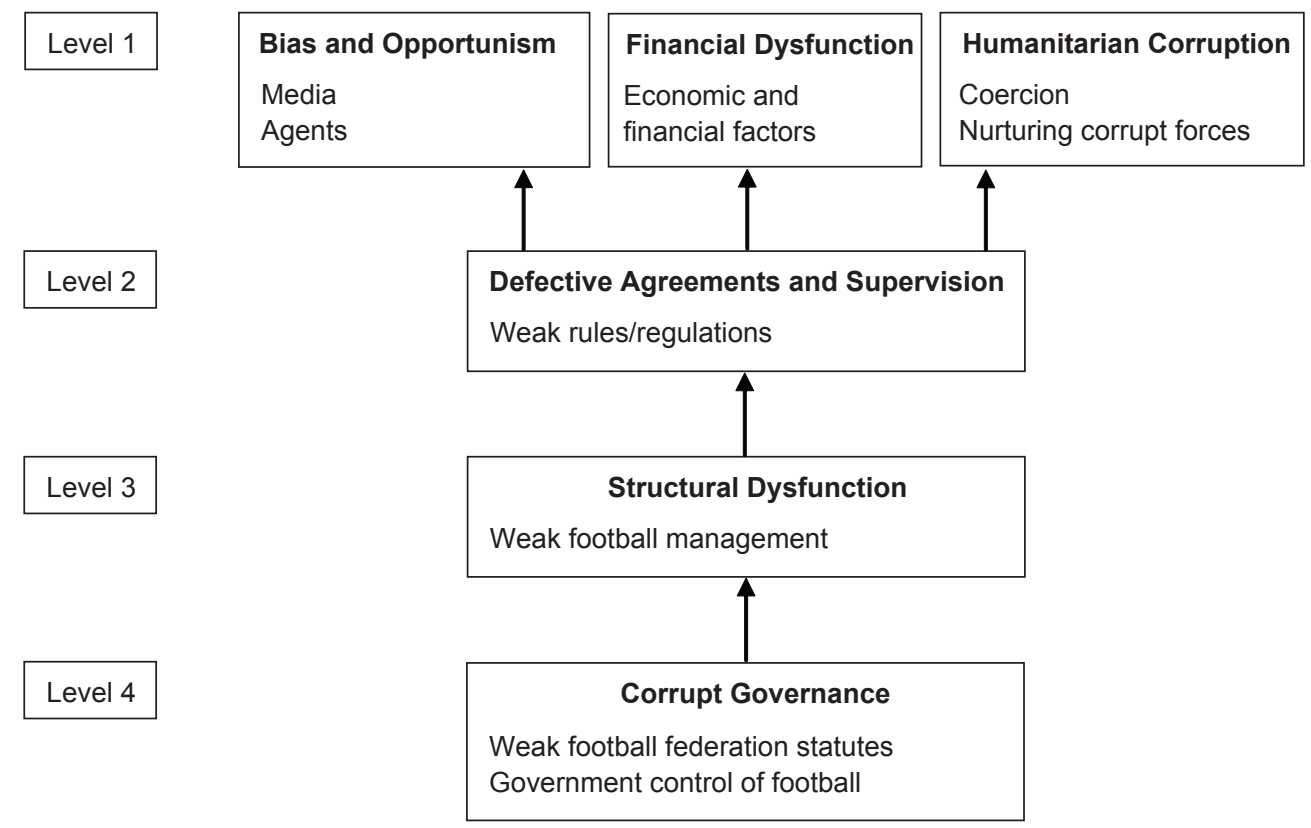

Figure 1. The interpretive structural model of corruption formation in Iranian football

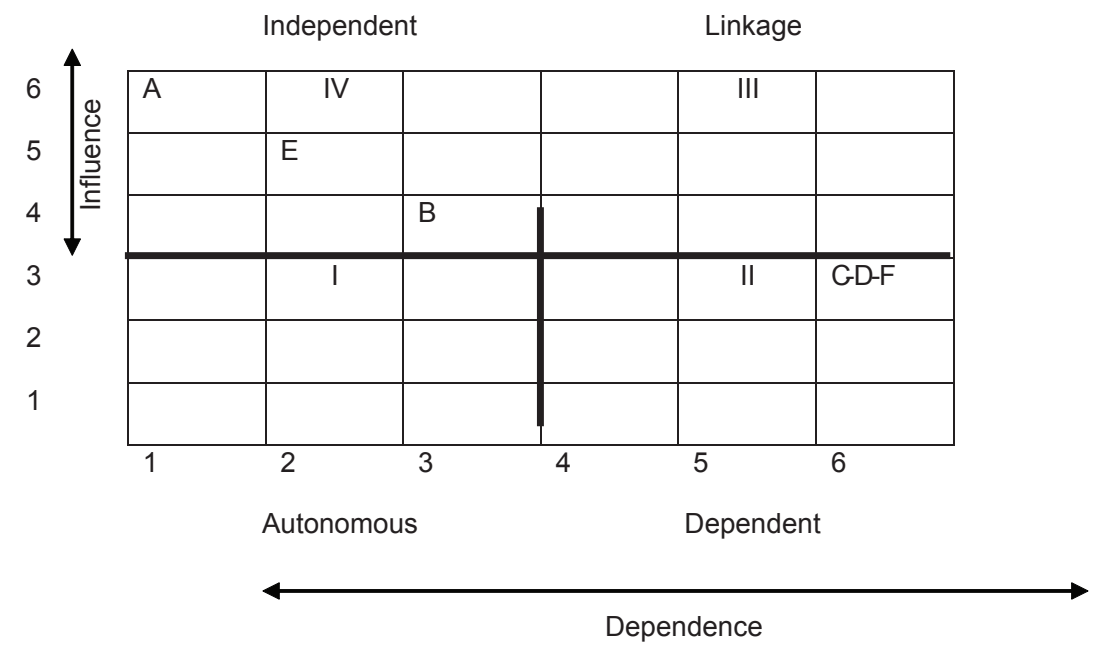

Figure 2. MICMAC graph

Note: (A) Corrupt governance of football; (B) Defective agreements and supervision; (C) Corruption of human resources; (D) Bias and opportunism; (E) Structural dysfunction; (F) Financial dysfunction.

In Figure 2, Quadrant 2 contains the dependent variables in the model. These variables have very strong dependence on the other variables (A, E, B) but weak influence. Quadrant 4 contains the variables with high influence and low dependence on the other variables $(\mathrm{C}, \mathrm{D}, \mathrm{F})$

\section{Discussion}

The purpose of this study was to use an interpretive structural modeling approach to explore the formation of corruption in the Iranian football industry. According to the results of this study, corruption is underpinned by corrupt governance and more specifically, weak federation statutes, government control of football, and weak governance. Corrupt governance creates structural dysfunction which is reflected in poor football management and flawed supervision. Defective agreements and supervision ensue from this structural dysfunction. Most notably, 
the defective agreements include weak rules/regulations and inefficient national and club contracts. The results of this study are consistent with the results of Najafi et al. (2020), Mansouri et al. (2019), Ghorbani et al. (2019), Mahmoudi et al. (2019), Shafiee et al. (2018), Goodarzi et al. (2010), Nunkoo et al. (2018), Brooks et al. (2013), and Mason, Thibault and Misener (2006). The key variables that cause financial corruption in the Iranian football industry - corrupt governance of football, defective agreements and supervision, and structural dysfunction all have high influence and low dependence.

According to the structural-interpretive diagram, corruption of human resources (i.e., coercion and nurturing corrupt human resources), bias and opportunism by journalists and agents, and financial dysfunction (i.e., money laundering and economic and financial factors) were located in the dependent cluster (Quadrant 2). The results of this finding are consistent with the results of Ghorbani et al. (2019), Mahmoudi et al. (2019), Mohammadi et al. (2020), Andreff (2018), and Kihl (2017). The dependent variables have high dependence or high performance but have low influence or importance. Moreover, independent variables are highly influential in the formation of these dependent variables. Therefore, any attempts at eliminating corruption that do not address these independent variables (i.e., corrupt governance of football, defective agreements and supervision, structural dysfunction) will likely be unsuccessful. Eliminating these independent variables ought to be the priority.

Good governance, or at the very least, corruption free governance, is an integral part of sustainable development for any organization (Bebchuk et al., 2013). However, in this study, the lack of good governance in the football industry has allowed corruption to permeate all aspects of the Iranian football industry. The weakness of the statutes of Iran's Football Federation is well recognized. Such weaknesses enable dismissals and recruitments to be based on political ideals and individual preferences without specialized knowledge. When there is weakness and ambiguity in the law, corruption and illegal behaviours will likely emerge. Thus, to optimize the context of football so that it enjoys governance and discipline, it is necessary to pay attention to proper governance and the adoption of appropriate, all-inclusive laws.

Corruption in Iranian football is facilitated by the government's control of football in Iran. Most of the professional football clubs in Iran can be divided into three groups: affiliated with state-owned industry, affiliated with the military, and affiliated with the Ministry of Sports and Youth. This impacts the independence and law-based and codified state of proper governance. As long as Iranian football is run by government-appointed officials, Iranian football will continue to be inefficient and ineffective. Such appointments, also make it difficult for stakeholders to criticize such appointments. It is also problematic that media organizations lack independence from the Iranian government. Hence, public scrutiny of state-controlled football teams remains a challenge.

In the remainder of this section, we propose a number of recommendations. Club privatization is a likely solution to reducing government control. Privatization can significantly increase the productivity of organisations and industries alike. In addition to solving the public-sector problems, privatization can go a long way in increasing public participation, competition, clubs' profitability, and the economic prosperity of the football industry. Transferring ownership of football clubs to individuals and the private sector is considered normal and legal in most countries of the world. Still, this issue has not yet found legal and executive validity in Iran. The issue of the state-ownership of professional football clubs is highly unreasonable, and in many jurisdictions, entirely illegal (Khabiri, 2003). For example, FIFA has issued a directive to the national member federations that a company can only own one club. The concern here is the potential for financial misconduct or collusion (Morrow, 1999). Now, if government is viewed as a single entity, the simultaneous ownership of several clubs by a government is arguably in contravention of FIFA policy.

In terms of defective agreements and supervision, the football federation should endeavor to eliminate the weak management practices. This includes, but is not restricted to the clubs' lack of attention to meritocracy and the professional competencies of the managers, their staff, and the coaches. The football federation must improve its supervision of officials and other employees in the industry. Proper management is integral to improving Iranian football (Gohari et al., 2021). This supports the argument that improved laws, better governance, and more competent managers results in less corruption (Nezlek et al., 2019).

A new Iranian football industry characterized by good governance, independence from government, and effective contracts and agreements will not emerge in a vacuum. Preventing corruption in Iranian football requires a national will to do so. Anti-corruption plans need to have short-term, medium-term, and long-term horizons. These plans must be developed independently of government. If privatization occurs, then the media should at least be allowed, and perhaps even encouraged, to expose corrupt behaviours. The academic community should also leverage whatever academic freedom they have to provide public commentary and empirical support for the value of good governance and the harm of poor and or corrupt governance. Sport management academics should also lend their expertise to helping Iranian football teams to privatize. 


\section{Conclusion}

This study identifies three factors that are key to sustaining corruption in the Iranian football industry: the corrupt governance of football (i.e., weak federation statutes, the government's control of football, and weak governance in football), defective agreements and supervision (i.e., weak laws and regulations; inefficient national and club contracts), and, finally, structural dysfunction (i.e., poor management and inadequate supervision in football). As long as these factors remain, efforts to reduce or eliminate corruption will be ineffective. Our findings provide the government and other regulatory bodies with specific issues to address. The findings send a clear message that good governance is essential for preventing corruption in football.

\section{References}

Agatiello, O. R. (2010). Corruption not an end. Management Decision, 48(10), 1456-1468. https://doi. org/10.1108/00251741011090270

Andreff, W. (2018). Different types of manipulation in sport. In M. Breuer \& D. Forrest (Eds.), The Palgrave Handbook on the Economics of Manipulation in Sport (pp. 13-35). Palgrave.

Attri, R., Grover, S., Dev, N., \& Kumar, D. (2013). Analysis of barriers of total productive maintenance (TPM). International Journal of System Assurance Engineering and Management, 4(4), 365-377. https://doi.org/10.1007/s13198012-0122-9

Azar, A., \& Khorrami, A. (2020). Designing a supply chain resilience model in the pharmaceutical industry with an Interpretive Structural Modeling Approach (ISM). Journal of International Business Administration, 3(10), 1-31. 10.22034/jiba.2020.11197

Bebchuk, L. A., Cohen, A., \& Wang, C. C. (2013). Learning and the disappearing association between governance and returns. Journal of Financial Economics, 108(2), 323-348. https://doi.org/10.1016/j.jfineco.2012.10.004

Brooks, G., Aleem, A., \& Button M. (2013). Fraud, Corruption and Sport: Palgrave Macmillan. https://doi. org/10.1057/9781137290717_5

Buraimo, B., Migali, S., \& Simmons, R. (2012). Corruption does not pay: An analysis of consumer response to Italy's Calciopoli Scandal, Working Paper, Lancaster University, Management School.

Constantin, P.-N., \& Stănescu, M. (2021). Irregularities in football. 'Cooperativa': A history of match-fixing in Romanian football. International Journal of the History of Sport, 37(15), 1549-1568. https://doi.org/10.1080/09523367.2020.1 828358

Dandah, G., \& Chiweshe, M. K. (2021). Zimbabwe premier soccer league in the context of COVID 19. Journal of Global Sport Management. https://doi.org/10.1080/24704067.2021.1899768

Dimant, E. (2014). The Antecedents and Effects of Corruption-A Reassessment of Current (Empirical) Findings. MPRA Paper 60947, University Library of Munich, Germany.

Farris D. R., \& Sage A. P. (1975). On the use of interpretive structural modeling for worth assessment, Computer and Electrical Engineering, 2, 149-174. https://doi.org/10.1016/0045-7906(75)90004-X

Ghai, K., \& Zipp, S. (2020). Governance in Indian cricket: Examining the Board of Control for Cricket in India through the good governance framework. Sport in Society, 24(5), 830-845.: https://doi.org/10.1080/17430437.2020.1819598

Ghorbani, M. H., Mohammadi, E., \& Zareian, H. (2019). Designing a model of corruption management in Iran sport. New Trends in Sport Management, 7(26), 121-138. http://ntsmj.issma.ir/article-1-1207-fa.html

Gohari, Z., Hamidi, M., \& Amirhosseini, E. (2021). The design and formulation of strategies for the improvement of football in the country. Majlis and Rahbord, 27(104), 291-321.

Goodarzi, M., Ghorbani, M., Poursoltani, H., \& Safari, H. (2010). Study of effective factors on the occurrence and growth of perceived corruption and its control methods in sports organizations in Iran. Sport Management Studies, 3(10), 39-56.

Gorse, S., \& Chadwick, S. (2011). The prevalence of corruption in international sport. Report prepared for the Remote Gambling Association and their Partners, the European Gaming and Betting Association and the European Sports Security Association. Retrieved from http://www.jogoremoto.pt/docs/extra/G3jsJk.pdf

Graycar, A. (2015). Corruption: Classification and analysis. Policy and Society, 34(2), 87-96. https://doi.org/10.1016/j. polsoc.2015.04.001

Hallmann, K., Dickson, G., \& Giesen, N. (2020). Determinants of image and image fit: A study of four sports and their domestic and international governing organizations. Communication and Sport, 1-19. https://doi. org/10.1177/2167479520929266 
Hauser, C., \& Hogenacker, J. (2014). Do firms proactively take measures to prevent corruption in their international operations? European Management Review, 11(3-4), 223-237. https://doi.org/10.1111/emre.12035

Khabiri, M., \& Elahi, A. (2003). Comparing the situation with the criteria of UEFA's professional football league clubs and clubs from the countries of Japan, South Korea, UAE and Turkey. Institute of Physical Education and Sport Sciences, Ministry of Science, Research and Technology, 3(8), 15-34.

Kihl, L. A., Ndiaye, M., \& Fink, J. (2018). Corruption's impact on organizational outcomes. Social Responsibility Journal, 14(1), 40-60. https://doi.org/10.1108/SRJ-12-2016-0217

Kihl, L. A, Skinner, J., \& Engelberg, T. (2017). Corruption in sport: understanding the complexity of corruption. European Sport Management Quarterly, 17(1), 1-5. https://doi.org/10.1080/16184742.2016.1257553

Kim, S., \& Wagner, S. M. (2021). Examining the stock price effect of corruption risk in the supply chain. Decision Sciences, 52(4), 833-865. https://doi.org/10.1111/deci.12487

Leby, J. L., \& Hashim, A. H. (2010). Liveability dimensions and attributes: Their relative importance in the eyes of neighborhood residents. Journal of Construction in Developing Countries, 15(1), 67-91.

Madhushani, A. A. L. (2019). Challenges in integrity of sport: Current practices and preventive approaches of sport corruption in Sri Lanka. Physical Culture and Sport, Studies and Research, 84(1), 21-26. https://doi.org/10.2478/pcssr2019-0023

Mahmoudi, A., Honar, H. I., Younesi, J., \& Shahlaee Bagheri, J. (2019). Determine strategies and consequences of administrative integrity in football industry of Iran. Sport Management and Development, 8(1), 16-30. 10.22124/ jsmd.1970.3436

Mansouri, H., Rezaei, Z., Sajadi, N., \& Mohammadi, M. (2019). Identification and prioritization of financial corruption indicators in Iran's sports organizations using hierarchical analysis approach. Sport Management and Development, 8(3), 58-70. https://dx.doi.org/10.22124/jsmd.2019.3798

Mason, D. S., Thibault, L., \& Misener, L. (2006). An agency theory perspective on corruption in sport: The case of the International Olympic Committee. Journal of Sport Management, 20(1), 52-73. http://dx.doi.org/10.1123/jsm.20.1.52

Matheson, V. A., Schwab, D., \& Koval, P. (2018). Corruption in the bidding, construction and organisation of megaevents: An analysis of the Olympics and World Cup. In M. Breuer \& D.Forrest (Eds.), The Palgrave Handbook on the Economics of Manipulation in Sport (pp. 257-278). https://crossworks.holycross.edu/econ_working_papers/185

Manoli, A. E., \& Janečić, D. (2020). Challenges to the role of media in reporting sport corruption: Insights from reporters in Balkan countries. International Review for the Sociology of Sport, 56(6) 842-858. https://doi. org/10.1177/1012690220967284

Manoli, A. E., Yilmaz, S., \& Antonopoulos, G. A. (2021). Match-fixing in Greece and Turkey and UEFA's policy responses to it: A comparative study. International Journal of Sport Policy and Politics, 13(1), 143-158. https://doi.org $/ 10.1080 / 19406940.2021 .1877172$

Marchetti, F., Reppold Filho, A. R., \& Constandt, B. (2021). At risk: Betting-related match-fixing in Brazilian football. Crime, Law and Social Change, https://doi.org/10.1007/s10611-021-09971-0

Monteduro, F., Cecchetti, I., Lai, Y., \& Allegrini, V. (2021). Does stakeholder engagement affect corruption risk management? Journal of Management and Governance, 25(3), 759-785. https://doi.org/10.1007/s10997-020-09527-9

Monteduro, F., Hinna, A., \& Moi, S. (2016). Governance and corruption in the public sector: An extended literature review. Governance and Performance in Public and Non-Profit Organizations - Studies in Public and Non-Profit Governance, 5, 31-51. https://doi.org/10.1108/S2051-663020160000005002

Moriconi, M. (2020). Deconstructing match-fixing: A holistic framework for sport integrity policies. Crime, Law and Social Change, 74(1), 1-12. https://doi.org/10.1007/s10611-020-09892-4

Morrow, S. (1999). The new business of football. MacMillan.

Müller, M. (2015). The mega-event syndrome: Why so much goes wrong in megaevent planning and what to do about it. Journal of the American Planning Association, 81(1), 6-17. https://doi.org/10.1080/01944363.2015.1038292

Najafi, M., Hami, M., Shojaei, V., Bagherian, \& Farahabadi, M. (2020). Identifying and analyzing factors affecting financial corruption in the Iranian sports industry. Applied Research in Sport Management, 9(1), 119-134. https://doi. org/10.1016/j.margen.2021.100866

Nezlek, J. B., Newman, D. B., Schütz, A., Baumeister, R. F., Schug, J., Joshanloo, M., Lopes, P. N., Alt, N. P., Cypryańska, M., Depietri, M., Gorbaniuk, O., Huguet, P., Kafetsios, K., Koydemir, S., Kuppens, P., Park, S., Martin, A. S., Schaafsma, J., Simunovic, D., \& Yokota, K. (2019). An international survey of perceptions of the 2014 FIFA World Cup: National levels of corruption as a context for perceptions of institutional corruption. PloS One, 14(9), e0222492. https://doi.org/10.1371/journal.pone.0222492 
Nunkoo, R., Ribeiro, M. A., Sunnassee, V., \& Gursoy, D. (2018). Public trust in mega event planning institutions: The role of knowledge, transparency and corruption. Tourism Management, 66, 155-166. https://doi.org/10.1016/j. tourman.2017.11.010

Olmos, L., Bellido, H., \& Román-Aso, J. A. (2020). The effects of mega-events on perceived corruption. European Journal of Political Economy, 61, 101826. https://doi.org/10.1016/j.ejpoleco.2019.101826

Philippou, C. (2019). Towards a unified framework for anti-bribery in sport governance. International Journal of Disclosure and Governance, 16(2), 83-99. https://doi.org/10.1057/s41310-019-00058-w Pielke, R. (2013). How can FIFA be held accountable? Sport Management Review, 16(3), 255-267. https://doi.org/10.1016/j.smr.2012.12.007

Poduval, P. S., Pramod, V. R. \& V. P., J. R. (2015). Interpretive Structural Modeling (ISM) and its application in analyzing factors inhibiting implementation of Total Productive Maintenance (TPM). International Journal of Quality \& Reliability Management, 32(3), 308-331. https://doi.org/10.1108/IJQRM-06-2013-0090

Pramod, V. R., \& Banwet, D. K. (2013), Analysing the synergic power of inhibitors of an Indian telecom supply chain. International Journal of Business Excellence, 6(4), 448-471. 10.1504/IJBEX.2013.054721

Ramesh, A., Banwet, D. K., \& Shankar, R. (2010). Modeling the barriers of supply chain collaboration. Journal of Modelling in Management, 5(2), 176-193. https://doi.org/10.1108/17465661011061014

Stathopoulou, A., Quansah, T. K., \& Balabanis, G. (2021). The blinding effects of team identification on sports corruption: Cross-cultural evidence from sub-saharan African countries. Journal of Business Ethics. https://doi.org/10.1007/ s10551-021-04822-3

Sushil, S. (2012). Interpreting the interpretive structural model. Global Journal of Flexible Systems Management, 13(2), 87-106. https://doi.org/10.1007/s40171-012-0008-3

Tzeng, C.-C., \& Lee, P.-C. (2021). Understanding match-fixing from the perspective of social capital: A case study of Taiwan's professional baseball system. International Review for the Sociology of Sport, 56(4), 558-577. https://doi. org/10.1177/1012690220917060

Warfield, J. W. (1974). Developing interconnected matrices in structural modelling, IEEE Transactions on Systems, Man and Cybernetics, 4(1), 81-87. 10.1109/TSMC.1974.5408524.

Weitz-Shapiro, R., \& Winters, W. S. (2017). Can citizens discern? Information credibility, political sophistication, and the punishment of corruption in Brazil. Journal of Politics, 79(1), 60-74. https://doi.org/10.1086/687287

Zhang, J. J., Kim, E., Mastromartino, B., Qian, T. Y., \& Nauright, J. (2018). The sport industry in growing economies: Critical issues and challenges. International Journal of Sports Marketing and Sponsorship, 19(2), 110-126. https:// doi.org/10.1108/IJSMS-03-2018-0023

This is Open Access article distributed under the terms of CC-BY-NC-ND 4.0 International License. 